\title{
19. Summary tables to include in a living wage report
}

Summary tables Tables 19.1 and 19.2 are important parts of a living wage report because they indicate in an easy to see way how a living wage was estimated. This increases transparency. This chapter includes and describes these summary tables. Note that whenever possible a living wage should be expressed in a way that is familiar to stakeholders such as a daily wage or a monthly wage.

Table 19.1 has three parts. Part I indicates costs for a basic but decent standard of living for the reference size family. This information can also be used in living income reports and estimates that are concerned with livelihoods of small farmers and businesses. Part II indicates the gross living wage and net take home pay living wage. Part III indicates basic cash living wages (gross and net) that workers would need assuming that they receive typical cash allowances and in kind benefits in an industry or establishment of interest.

Table 19.2 indicates some key values and assumptions used to estimate the living wage.

Table 19.1 Summary table to calculate a living wage (to include in a living wage report)

\begin{tabular}{|l|l|l|}
\hline PART I. FAMILY EXPENSES & $\begin{array}{l}\text { Local } \\
\text { currency }\end{array}$ & USD \\
\hline Food cost per month for reference family (1) & & \\
\hline Food cost per person per day & & \\
\hline Housing costs per month (2) & & \\
\hline Rent per month for acceptable housing ${ }^{\text {a }}$ & & \\
\hline Utility costs and minor repairs per month & $\begin{array}{l}\text { Non-food non-housing (NFNH) costs per month taking into } \\
\text { consideration post checks (3) }\end{array}$ & \\
\hline Preliminary estimate of NFNH costs & \\
\hline Health care post check adjustment & & \\
\hline
\end{tabular}


Table 19.1 (continued)

\begin{tabular}{|c|c|}
\hline Education post check adjustment & \\
\hline Other possible post check adjustments (if any) & \\
\hline Additional amount (5\%) for sustainability and emergencies (4A) & \\
\hline $\begin{array}{l}\text { Possible additional amount (usually 5\%) for extended family } \\
\text { support (4B) }\end{array}$ & \\
\hline $\begin{array}{l}\text { Total costs per month for basic but decent living standard for } \\
\text { reference family }(5)[5=1+2+3+4 A+4 B]\end{array}$ & \\
\hline PART II. LIVING WAGE PER MONTH & \\
\hline Net living wage per month $(6)[6=5 / \#$ full-time workers $]$ & \\
\hline Statutory deductions from pay (7) (list these in notes to table) ${ }^{b}$ & \\
\hline Gross living wage per month $(8)[8=6+7]$ & \\
\hline $\begin{array}{l}\text { WHEN LIVING WAGE STUDY HAS AN INDUSTRY OR } \\
\text { ESTABLISHMENT FOCUS }\end{array}$ & \\
\hline $\begin{array}{l}\text { PART III: CASH (BASIC) LIVING WAGE ASSUMING WORI } \\
\text { RECEIVE TYPICAL IN-KIND BENEFITS, AND TYPICAL } \\
\text { ALLOWANCES AND TYPICAL BONUSES AND BENEFI } \\
\text { INDUSTRY OR ESTABLISHMENT }\end{array}$ & $\begin{array}{l}\text { KERS } \\
\text { CASH } \\
\text { TS IN AN }\end{array}$ \\
\hline $\begin{array}{l}\text { Value per month of common in-kind benefits in industry or } \\
\text { establishment (9A) (indicate in notes to table) }\end{array}$ & \\
\hline $\begin{array}{l}\text { Value per month of common cash allowances and bonuses and } \\
\text { benefits in an industry or establishment (9B) (indicate in notes } \\
\text { to table) }^{\mathrm{d}}\end{array}$ & \\
\hline $\begin{array}{l}\text { Net cash (basic) living wage assuming workers receive typical } \\
\text { in-kind benefits, cash allowances, bonuses, and benefits in an } \\
\text { industry or establishment }(10)[10=6-9 A-9 B]\end{array}$ & \\
\hline $\begin{array}{l}\text { Gross cash (basic) living wage assuming workers receive typical } \\
\text { in-kind benefits, cash allowances, bonuses, and benefits in an } \\
\text { industry or establishment }(11)[11=8-9 A-9 B]\end{array}$ & \\
\hline
\end{tabular}

Notes:

a In locations with little or no rental housing market, indicate user cost for acceptable owner-occupied house.

b Statutory deductions from pay include the following items and percentages:

c Common in kind benefits include the following items and values:

d Common cash allowances and bonuses include the following items and amounts: 
Table 19.2 Key values and assumptions used to estimate living wage (to include in a living wage report)

\begin{tabular}{|l|l|}
\hline Key values and assumptions & \\
\hline Location (industry or establishment if relevant) & \\
\hline Exchange rate of local currency to USD & \\
\hline Number of full-time workdays per month & \\
\hline Number of hours in normal workweek & \\
\hline Number of full-time workers per couple & \\
\hline Reference family size & \\
\hline Number of children in reference family & \\
\hline Preliminary ratio of NFNH costs to FOOD costs & \\
\hline
\end{tabular}

